\title{
Application of Color and Size Measurement in Food Products Inspection
}

\author{
J Siswantoro ${ }^{* 1}$ \\ ${ }^{1}$ Department of Informatics Engineering, Universitas Surabaya, Jl. Kali Rungkut, \\ Surabaya, 60293, Indonesia \\ E-mail: joko_siswantoro@staff.ubaya.ac.id ${ }^{1}$
}

Masuk: 22 Januari 2019, direvisi: 16 Februari 2019, diterima: 21 Februari 2019

\begin{abstract}
Abstrak. Warna dan ukuran adalah aspek eksternal yang dipertimbangkan oleh konsumen dalam membeli produk makanan dan digunakan dalam inspeksi produk makanan menggunakan computer vision. Paper ini mengulas aplikasi terbaru pengukuran warna dan ukuran dalam inspeksi produk makanan menggunakan computer vision. RGB, HSI, HSL, $\mathrm{HSV}, \mathrm{La} * \mathrm{~b}$ spasi dan indeks warna banyak digunakan untuk mengukur warna dalam inspeksi produk makanan. Fitur warna, termasuk nilai, rerata, varian, dan standar deviasi setiap saluran dalam ruang warna banyak digunakan dalam inspeksi produk makanan. Aplikasi pengukuran warna dalam inspeksi produk makanan adalah untuk penilaian, deteksi anomali atau kerusakan, deteksi konten spesifik, dan evaluasi perubahan warna. Panjang, lebar, tebal, radius rata-rata, Diameter Feret, luas, keliling, volume, dan luas permukaan adalah ukuran umum dalam inspeksi produk makanan. Aplikasi pengukuran ukuran dalam inspeksi produk makanan adalah untuk memperkirakan ukuran, menyortir, menilai, mendeteksi benda atau cacat yang tidak diinginkan, dan pengukuran sifat fisik.
\end{abstract}

Kata kunci: warna; ukuran; produk makanan; inspeksi

\begin{abstract}
Color and size are external aspects considered by consumers in purchasing a food product and are used in food product inspection using computer vision. This paper reviews recent applications of color and size measurement in food product inspection using computer vision. RGB, HSI, HSL, HSV, La*b spaces and color index are widely used to measure color in food product inspection. Color features, including value, mean, variance, and standard deviation of each channel in a color space are widely used in food product inspection. The applications of color measurement in food product inspection are for grading, detection of anomaly or damage, detection of specific content and evaluation of color changes. Length, width, thickness, average radius, Feret's diameter, area, perimeter, volume, and surface area are common size measurements in food product inspection. The applications of size measurement in food product inspection are for estimating size, sorting, grading, detect unwanted objects or defects, and measurement of physical properties.
\end{abstract}

Keywords: color; size; food product; inspection

\section{Introduction}

Visual quality is an important criterion for consumers in purchasing a food product on the market [1]. Consumers will choose a product with better quality, although the price is slightly more expensive. On the other hand, by selling products with better quality producers will gain multiple benefits, the 
product will be sold quickly at the best price and a higher profit is obtained. Quality of a product consists of external quality and internal quality. External quality is usually assessed visually by the consumer. To assess the visual quality, consumers will consider a combination of several external aspects such as color, size, shape, and texture [2].

Traditionally, the quality of a food product is inspected by a human expert, one by one or using large batches as samples. The Inspector assesses the product by seeing and feeling, to detect defects, colors, sizes or strange features, and classifies the product in its appropriate category [3]. This method is very costly, time consuming, of high variability, and inconsistent [3][4]. With the increasing demand for high-quality food products which must be fulfilled quickly and the demands of current security and food safety, traditional inspections would not be able to cope with these requirements.

To replace the role of traditional inspection, currently automated visual inspection system for food products using computer vision has been widely used in many countries [5]. Automated visual inspection is one of the main applications of computers vision [6]. It has been used in quality inspection for various types of food products, including apples, oranges, potatoes, carrots, beef, pork, etc. [7]. Automated visual inspection systems consist of one or more cameras to acquire images of the inspected object, a personal computer, lighting sources and then utilizing appropriate image processing hardware and software routines to find and classify areas of interest in the images, as shown in figure 1 [8][9]. In general an automated visual inspection system involves a series of processing stages including image acquisition, image enhancement, segmentation, feature extraction, and object classification [9][10].

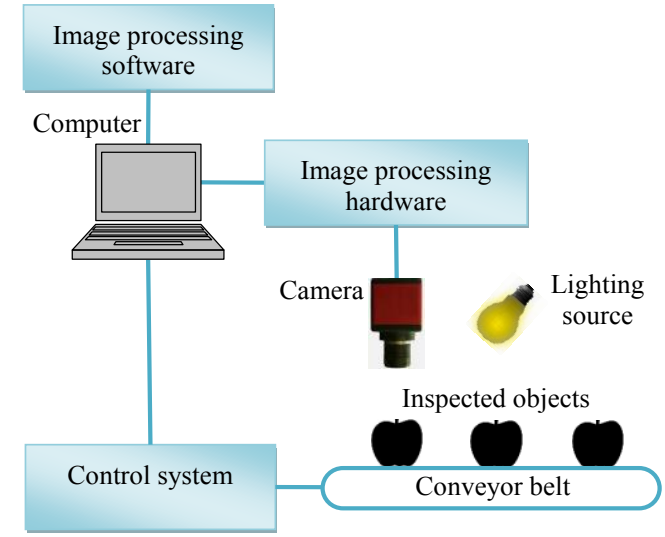

Figure 1. The structure of visual inspection system

The aim of this paper is to review recent applications of color and size measurement in food product inspection using computer vision. The importance and measurement methods of color and size are discussed to provide information for researchers as consideration in using such features. Applications of color and size measurement in food product inspection are given together with their result accuracies.

\section{Color Measurement}

Surface color of a food product is the first-quality parameter that is seen by consumers. Often consumers will accept or reject a food product based on the color of its surface [11]. Color also influences the price of certain foods such as apples [12][13]. With color, we will be able to detect the presence of any particular damage in the product, to detect the specific content in food products [7][14][15], to evaluate changes of product color during processing [2], and to evaluate fruit maturity [16], etc. To measure color of a food product the image of object is acquired using a single camera. The acquired image is then processed to extract the color of the object in a certain color space. Color measurement of a food product can be done in several color spaces. Zheng and Sun classified color spaces into three types: hardware-oriented spaces, human-oriented spaces, and instrumental spaces 
[17]. Moreover, color measurement, particularly on a food product, can also be performed by means of a color index [16].

\subsection{Hardware-oriented spaces}

Hardware-oriented spaces are usually used in hardware processing, such as capturing, storing, and displaying. These spaces include RGB, YIQ, YUV, YCbCr, YCC, and CMYK spaces. The RGB (red, green, blue) space is the most popular hardware-oriented space, which is used in most computers and cameras. This space is an additive color system based on tri-chromatic theory [18]. Color in RGB spaces is defined as three components in three dimensional coordinates with axes $R, G, B$. According to [19] the value of the $R, G, B$ components is the sum of the respective sensitivity functions and the incoming light.

YIQ (luminance, in-phase, and quadrature) and YUV spaces are used in the NTSC American and PAL European TV transmission systems respectively. $Y$ is the luminance component; $I, Q$ and $U, V$ are chrominance components. The value of YIQ and YUV spaces can be obtained from RGB space using the following linear transformations shown in equation (1) [19].

$$
\left[\begin{array}{l}
Y \\
I \\
Q
\end{array}\right]=\left[\begin{array}{ccc}
0.299 & 0.587 & 0.114 \\
0.596 & -0.275 & -0.321 \\
0.207 & -0.497 & 0.290
\end{array}\right]\left[\begin{array}{l}
R \\
G \\
B
\end{array}\right]\left[\begin{array}{l}
Y \\
U \\
V
\end{array}\right]=\left[\begin{array}{ccc}
0.299 & 0.587 & 0.114 \\
-0.147 & -0.289 & 0.437 \\
0.615 & -0.515 & -0.100
\end{array}\right]\left[\begin{array}{l}
R \\
G \\
B
\end{array}\right]
$$

Similar to YIQ and YUV spaces, YCbCr is also used in TV transmission but in digital standard. The YCC space is used by Kodak in its PhotoCD system. CMYK (cyan, magenta, yellow, black) space is a subtractive based color space and is mainly used in printing and hard copy output. The value of YCbCr, YCC, and CMYK spaces can be obtained in a similar way as the value of YIQ space by linear transformation from RGB space. Hardware-oriented spaces are device dependent and non-linear with regard to the visual perception of human eyes [18]. As a consequence of non-linearity, they are not capable of evaluating the sensory properties of food products [17].

\subsection{Human-oriented spaces}

These spaces are developed according to the concepts of tint, shade, and tone, which are defined by an artist based on the intuitive color characteristics. HSI, HSV, and HSL spaces are included in these spaces. These spaces are defined as three components in cylindrical coordinates with axes $H$ (hue), $S$ (saturation), $I$ (intensity) (or $V$ (value), or $L$ (lightness)). Hue is measured by the distance of the current color position from the red axis, which is manifested by the difference in color wavelengths. Hue is the attribute whether the color is red, green, yellow, blue, or purple, etc. Saturation is a measurement of the amount of color. An extremely saturated color has only one spectral component while an unsaturated color has lots of white added. Intensity, value, or lightness refers to the brightness or luminance [19][16][17]. Transformation from RGB space to HSI space can be done using equation (2) [20].

$$
H=\left\{\begin{array}{c}
\cos ^{-1}\left(\frac{\frac{1}{2}[2 R-G-B]}{\left[(R-G)^{2}+(R-G)(G-B)\right]^{1 / 2}}\right) \quad \text { if } B \leq G \\
360-\cos ^{-1}\left(\frac{\frac{1}{2}[2 R-G-B]}{\left[(R-G)^{2}+(R-G)(G-B)\right]^{1 / 2}}\right) \text { if } B>G \\
S=1-\frac{\min (R, G, B))}{I} \\
I=\frac{R+G+B}{3}
\end{array}\right.
$$


Equation (3) is another transformation explained by Zheng and Sun to calculate the value of $\mathrm{H}$ in HIS space from RGB space [17].

$$
H=\left\{\begin{array}{l}
\frac{1}{2 \pi}\left[\frac{3 \pi}{2}-\tan ^{-1}\left(\frac{\frac{1}{2}[2 R-G-H]}{\sqrt{3}(G-B)}\right)\right] \text { if } G<B \\
\frac{1}{2 \pi}\left[\frac{\pi}{2}-\tan ^{-1}\left(\frac{\frac{1}{2}[2 R-G-H]}{\sqrt{3}(G-B)}\right)\right] \quad \text { if } G>B
\end{array}\right.
$$

The value of HSV color space is obtained using the following transformation shown in equation (4) [21]

$$
H=\left\{\begin{array}{c}
60\left(\frac{G-B}{\max (R, G, B)-\min (R, G, B)}\right) \quad \text { if } \max (R, G, B)=R \\
60\left(\frac{B-R}{\max (R, G, B)-\min (R, G, B)}+2\right) \text { if } \max (R, G, B)=G \\
60\left(\frac{R-G}{\max (R, G, B)-\min (R, G, B)}+3\right) \text { if } \max (R, G, B)=B \\
\text { not defined } \quad \text { if } \max (R, G, B)=0
\end{array}\right.
$$

The HSI space is the closest representation to the manner in which humans perceive color and it helps compress information for easier color discrimination [22]. Color measurements in HSI space have good relation with the color of food surface. There is greater correlation between the color measurements from human-orientated spaces and the sensory scores of food products. But, humanorientated color spaces are not suitable for evaluating changes of product color during processing because they are not sensitive to a small amount of color variation [17].

\subsection{Instrumental spaces}

These spaces are used for color instruments such as colorimeter and colorimetric spectrophotometer. Many of these spaces are standardized by the CIE (Commission International de L'Éclairage), which are CIE XYZ, CIE La*b*, and CIE Lu*v* color spaces. CIE standardized the XYZ values as tristimulus values. The XYZ space can describe any color that can be perceived by an average human observer. This color space is chosen in such a way that every perceptible visual stimulus is described with positive $\mathrm{XYZ}$ values. The XYZ color space is device independent and is usually used as a reference color space [19]. $Y$ is the lightness component; $X$ and $Z$ are two primary virtual components. Equation (5) is used to transform RGB space to $X Y Z$ space [17].

$$
\left[\begin{array}{l}
X \\
Y \\
Z
\end{array}\right]=\left[\begin{array}{lll}
0.412453 & 0.357580 & 0.180423 \\
0.212671 & 0.715160 & 0.072169 \\
0.019334 & 0.119194 & 0.950227
\end{array}\right]\left[\begin{array}{l}
R \\
G \\
B
\end{array}\right]
$$


The other CIE standard color spaces are La ${ }^{*}{ }^{*}$ and $\mathrm{Lu}^{*} \mathrm{v}^{*}$ space. These color spaces provide a perceptually equal space. It means that Euclidean distance between two colors in these spaces is strongly correlated with the human visual perception [19]. The color component $L$ is lightness or luminance; $\mathrm{a} *(\mathrm{u} *)$ and $\mathrm{b} *(\mathrm{v} *)$ are two chromatic components. $\mathrm{a} *(\mathrm{u} *)$ is defined along the axis of redgreen, and $\mathrm{b} *(\mathrm{v} *)$ is defined along the axis of yellow-blue. The value of $\mathrm{La}^{*} \mathrm{~b}^{*}$ and $\mathrm{Lu}^{*} \mathrm{v}^{*}$ spaces can be obtained by non-linear transformation from the XYZ space [17], as shown in equation (6).

$$
\begin{gathered}
L=\left\{\begin{array}{r}
116\left(Y / Y^{\prime}\right)^{1 / 3}-16 \text { if } Y / Y^{\prime}>0.008856 \\
903.0 Y / Y^{\prime} \\
\text { othrwise }
\end{array}\right. \\
a^{*}=500\left[\left(X / X^{\prime}\right)^{1 / 3}-\left(Y / Y^{\prime}\right)^{1 / 3}\right] \\
b^{*}=200\left[\left(Y / Y^{\prime}\right)^{1 / 3}-\left(Z / Z^{\prime}\right)^{1 / 3}\right] \\
u^{*}=13 L\left(u^{\prime}-u^{\prime \prime}\right) \\
v^{*}=13 L\left(v^{\prime}-v^{\prime \prime}\right)
\end{gathered}
$$

Where $X^{\prime}=95.047, Y^{\prime}=100, Z^{\prime}=108.883$ and

$$
\begin{array}{ll}
u^{\prime}=4 X /(X+15 Y+3 Z) & u^{\prime \prime}=4 X^{\prime} /\left(X^{\prime}+15 Y^{\prime}+3 Z^{\prime}\right) \\
v^{\prime}=9 X /(X+15 Y+3 Z) & v^{\prime \prime}=9 X^{\prime} /\left(X^{\prime}+15 Y^{\prime}+3 Z^{\prime}\right)
\end{array}
$$

Direct transformation from RGB space to $\mathrm{La}^{*} \mathrm{~b} *$ space can also be performed using a mathematical model or an artificial neural network (ANN) [11][23]. The mathematical model consists of several parameters with inputs being R, G, B values obtained from sample images and outputs are the estimation of $L, a^{*}, b^{*}$ values. The parameters of the model are estimated by minimization of the mean absolute error between estimated values $\hat{L}, \hat{a}^{*}, \hat{b}^{*}$ and $L, a^{*}, b^{*}$ sample values obtained from a colorimeter.

The mathematical model can be classified into linear parameter and non-linear parameter models. The linear parameter model consists of the linear, quadratic, and full quadratic models. The Linear model is the linear function of the $R, G, B$ values. The quadratic model is the function of $R^{2}, G^{2}, B^{2}$ while the full quadratic model is the function of $R, G, B, R G, R B, G B, R^{2}, G^{2}, B^{2}$. The linear parameters of the model can be estimated directly by simple linear regression.

The non-linear parameter model transforms RGB space to La*b* space in two steps [11]. First step transforms RGB space to XYZ space by a direct model or the Gamma model. The direct model transforms RGB space to XYZ space using the following linear transform shown in equation (7).

$$
\left[\begin{array}{l}
X \\
Y \\
Z
\end{array}\right]=\left[\begin{array}{lll}
M_{11} & M_{12} & M_{13} \\
M_{21} & M_{22} & M_{23} \\
M_{31} & M_{32} & M_{33}
\end{array}\right]\left[\begin{array}{l}
R \\
G \\
B
\end{array}\right]
$$

The Gamma model has added gamma correction parameters which correspond to the values $\alpha_{1}, \alpha_{2}$ and gamma factor $\gamma$, as shown in equation (8). 


$$
R^{\prime}=\left(\frac{R+\alpha_{1}}{\alpha_{2}}\right)^{\gamma}, G^{\prime}=\left(\frac{G+\alpha_{1}}{\alpha_{2}}\right)^{\gamma}, B^{\prime}=\left(\frac{B+\alpha_{1}}{\alpha_{2}}\right)^{\gamma}
$$

Then $X, Y, Z$ values are obtained by equation (9).

$$
\left[\begin{array}{l}
X \\
Y \\
Z
\end{array}\right]=\left[\begin{array}{lll}
M_{11} & M_{12} & M_{13} \\
M_{21} & M_{22} & M_{23} \\
M_{31} & M_{32} & M_{33}
\end{array}\right]\left[\begin{array}{c}
R^{\prime} \\
G^{\prime} \\
B^{\prime}
\end{array}\right]
$$

The second step transforms XYZ space to $\mathrm{La}^{*} \mathrm{~b}^{*}$ space using non-linear transformation shown in equation (6). In order to estimate parameters $M_{i j}$ in equation (7) and (9), a non-linear function of $M_{i j}$ is defined using equation (6). Parameters $M_{i j}$ are then estimated using some iterative method.

The architecture of ANN to transform RGB space to La*b* space consists of three neurons in the input layer which correspond to $R, G$, and $B$, three neurons in the output layers which correspond to $L$, $a^{*}$, and $b^{*}$, and one hidden layer. The best performance, without overtraining, is achieved with eight neurons in the hidden layer. Before training, $R, G, B$ values are normalized such that the values lie in the range $[0,1][11]$. The other architecture of ANN uses three different neural networks for $L, a^{*}$, and $b^{*}$. Each network consists of six neurons in the input layer which corresponds to $R, G, B$ values and their square and one neuron in the output layer. The best performance for these ANN is achieved with six neurons in the hidden layer. Before training, $R, G, B$ values are also normalized such that the values lie in the range $[-1,1][23]$.

\subsection{Color index}

Most food products have only a few numbers of colors of interest. The range of observed colors in grading a particular food product will be a very small subset of a color space. Therefore, the colors that are not present in a food product can be omitted in the grading process. For example, in tomato gridding, according to the United States Department of Agriculture (USDA), the color range of tomatoes at all possible maturity stages, with six distinct grades, are Green, Breakers, Turning, Pink, Light Red, and Red. Because of the limited number of color of interest in a food product, it is possible to map the range of colors of interest from 3D RGB space to a $1 \mathrm{D}$ color space that uses an index to represent a color in the certain range [16].

The third order term (RGB) and the full quadratic term $\left(R, G, B, R G, R B, G B, R^{2}, G^{2}, B^{2}\right.$, and constant) are used to map 3D RGB space to a 1D color index, as shown in equation (10).

$$
\begin{aligned}
\text { Colorindex }= & c_{1} R G B+c_{2} R^{2}+c_{3} G^{2}+c_{4} B^{2}+c_{5} R G+c_{6} R B+ \\
& c_{7} G B+c_{8} R+c_{9} G+c_{10} B+c_{11}
\end{aligned}
$$

The parameters $c_{i}$ are estimated using the least square method with a set of color of interest samples in RGB space and a set of desired color index that is specified by a human expert in the range from 0 to 255 for each color sample.

With the color index, color grading reliably meets industry standards for accuracy because it does not incorporate machine learning or artificial intelligence techniques. Moreover, setting the color preferences and making subsequent adjustments are both straightforward and easily accomplished by an operator without specialized training in image processing [16].

\section{Size Measurement}

Size is an important physical parameter for food products and a critical factor for consumers in choosing a food product. Size is important in harvesting, food processing, sorting, grading, packaging, transportation, marketing, and pricing. Size can be used to measure the shape of a product. With size, 
other physical properties of food product can be calculated [24]-[27]. To measure size of a food product, an image of the object is acquired using one or more cameras and it is then processed using a series of image processing techniques to obtain the object's silhouette. The size of the object is then measured from the silhouette.

\subsection{D Size Measurement}

1D size measurement of a food product is often performed even though the product is three dimensional, because the object will be reduced to being two dimensional in an image. Length, width, and thickness are widely used in 1D size measurement. However, these sizes are difficult to define for objects with irregular shape.

Length, width, and thickness are measured in a similar manner with the major axis and minor axis of an ellipse. Length is defined as the longest distance between two pixels in the boundary of an object and the line between them is the major axis. Width is defined as the longest distance between two pixels in the boundary of an object in a perpendicular direction to the major axis and the line between them is the minor axis. Thickness is defined as length of the minor axis in the other side [24].

The other 1D size measurements are average radius and Feret's Diameter. Average radius is defined as average of the distance from the centroid to the boundary points of the object [2]. Feret's Diameter is defined as the difference between the largest and the smallest of the pixel coordinates of an object at a different coordinate axis [17].

\subsection{D Size Measurement}

2D size measurements include area and perimeter. These sizes are easier to define than length and width. Area is usually referred to as the projected area of the product. It can be easily defined by counting the number of all pixels in the object. The perimeter is defined by summing up the distance between every two neighboring pixels on the boundary of the object [17].

\subsection{D Size Measurement}

Although 3D size measurements, such as volume and surface area, are more difficult, they have a very important role in the production and processing of food products. 3D size measurement can be classified into 3D size measurement for axi-symmetric objects and for objects with irregular shape.

3.3.1. Axi-symmetric object. An object is considered axi-symmetric if all the cross sections of the object along the major dimension axis are circular shape, such as on egg, watermelon, orange, etc. The projected area of the object is acquired using either single or double cameras. After image acquisition the image of the object is processed to produce the boundaries of the object. The required dimensional attributes for volume and surface area measurement are obtained from the boundaries. The volume and surface area of an axi-symmetric object can be modeled using solid of revolution, which are obtained by rotating half of the projected area of an object around its major axis.

3.3.1.1. Disk method. The disk method assumes that the object is the sum of disks. The upper half of the projected area is assumed as the sum of n rectangles with size $h \times D_{i} / 2$ for $i=1,2, \ldots, n$. Each rectangle is then rotated around the major axis to produce disks. The required dimensional attributes for volume measurement are the diameter (D) and height ( $h=1$ pixel) of the disk as shown in figure 2. The volume $(\mathrm{V})$ of the object is approximated by the sum of volume of $\mathrm{n}$ disks, as shown in equation (11) [28][27].

$$
V=\sum_{i=1}^{n} \pi\left(D_{i} / 2\right)^{2} h
$$




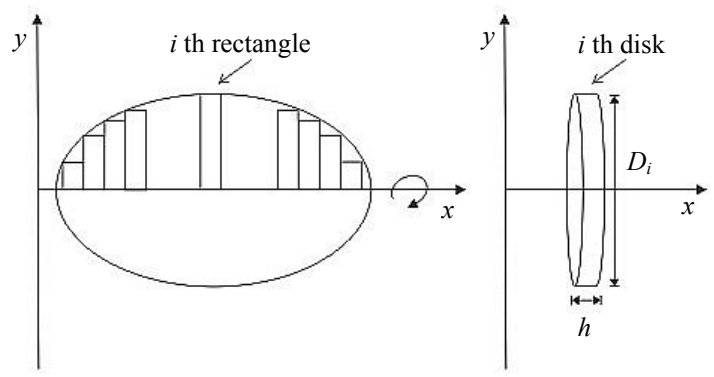

Figure 2. The required dimensional attributes for disk method

3.3.1.2. Conical frustum method. The conical frustum method assumes that the object is the sum of conical frustums. The upper half of the projected area is assumed as the sum of $n$ trapeziums with base $D_{\text {top }_{i}} / 2, D_{\text {bottom }_{i}} / 2$ for $i=1,2, \ldots, n$ and height $\mathrm{h}$. Each trapezium is then rotated around major axis to produce a frustum cone. The required dimensional attributes are the top diameter $\left(\mathrm{D}_{\text {top }}\right)$, bottom diameter $\left(\mathrm{D}_{\text {bottom }}\right)$ and height $(h=1$ pixel) of frustum as shown in figure 3 . The volume $(\mathrm{V})$ and surface area (S) of the object are approximated by the sum of volume and surface area of $n$ conical frustums respectively, as shown in equation (12) and (13) [29].

$$
\begin{gathered}
V=\sum_{i=1}^{n} \frac{\pi h}{12}\left(D_{\text {bottom }_{i}}^{2}+D_{\text {bottom }_{i}} D_{\text {top }_{i}}+D_{\text {top }_{i}}^{2}\right)^{2} \\
S=\sum_{i=1}^{n} \frac{\pi h}{12}\left(D_{\text {bottom }_{i}}+D_{\text {top }_{i}}\right) \sqrt{h^{2}+\left(D_{\text {bottom }_{i}} / 2-D_{\text {top }_{i}} / 2\right)^{2}}
\end{gathered}
$$

In estimating the surface area and volume of an ellipsoidal ham, Du and Sun modified the conical frustum method by assuming that the two end portions of the ham were spherical caps and the volume (V) and surface area (S) of the ellipsoidal ham were measured using equation (14) and (15) [30].

$$
\begin{gathered}
V=\sum_{i=1, n} \frac{\pi}{24}\left(3 D_{\text {bottom }_{i}}^{2}+4 h^{2}\right)+\sum_{i=2}^{n-1} \frac{\pi h}{12}\left(D_{\text {bottom }_{i}}^{2}+D_{\text {bottom } \left._{i} D_{\text {top }_{i}}+D_{\text {top }_{i}}^{2}\right)^{2}}\right. \\
S=\sum_{i=1, n} \frac{\pi}{4}\left(D_{\text {bottom }_{i}}^{2}+4 h^{2}\right)+\sum_{i=2}^{n-1} \frac{\pi h}{12}\left(D_{\text {bottom }_{i}}+D_{\text {top }_{i}}\right) \sqrt{h^{2}+\left(D_{\text {bottom }_{i}} / 2-D_{\text {top }_{i}} / 2\right)^{2}}
\end{gathered}
$$

Figure 3. The required dimensional attributes for conical frustum method

3.3.1.3. Elliptic conical frustum method. To increase the accuracy of the conical frustum method the cross-sectional surfaces of the conical cone are assumed elliptical with two perpendicular diameters $D_{1}$ and $\mathrm{D}_{2}$ extracted by two cameras as shown in figure 4 [31]. The volume (V) and surface area (S) of the object are approximated using equation (16) and (17).

$$
V=\sum_{i=1}^{n} \frac{h}{2}\left(A_{i}+A_{i+1}\right)^{2}
$$




$$
S=\sum_{i=1}^{n} \frac{\pi}{4}\left(D_{1 i}+D_{2 i}+D_{1(i+1)}+D_{2(i+1)}\right) \sqrt{h^{2}+\left(\frac{D_{1 i}+D_{2 i}}{4}-\frac{D_{1(i+1)}+D_{2(i+1)}}{4}\right)^{2}}
$$

Where $A_{i}=\pi D_{1 i} D_{2 i} / 4$ is the cross sectional area of the frustum.
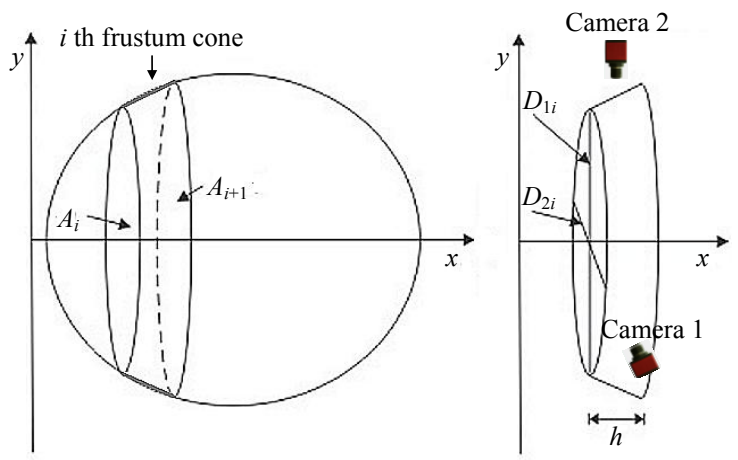

Figure 4. The required dimensional attributes for elliptic conical frustum method

3.3.1.4. Method based on Pappus theorem. To measure the volume egg, Soltani, Omid, and Alimardani used assumption that the shape of egg is obtained by rotating the two half of egg projection areas around its major axis of $180^{\circ}$ [32], as shown in figure 5. The volume of egg was then calculated based on the second centroid theorem of Pappus. The theorem states that the volume of a solid of revolution object generated by the revolution of a lamina about an external axis is equal to the product of the area $\mathrm{A}$ of the lamina and the distance $\mathrm{R}$ traveled by the lamina's geometric centroid, as in equation (18).

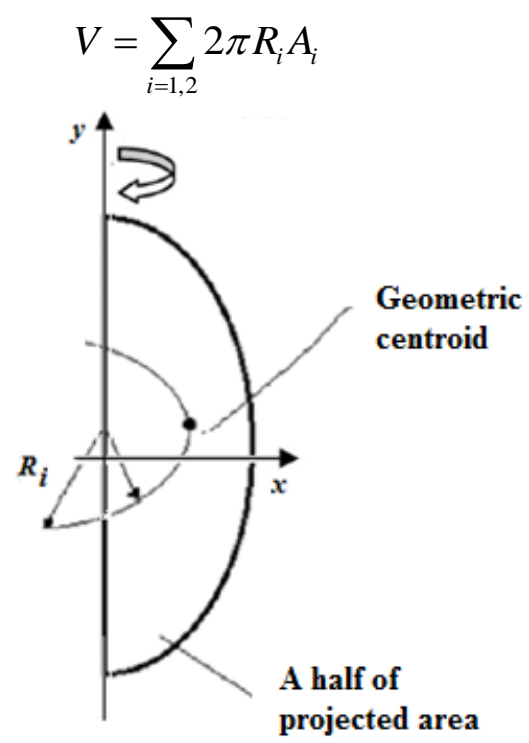

Figure 5. The illustration of volume measurement based on Pappus theorem

3.3.2. Irregular shape object. In 3D size measurement for objects with irregular shape, images of the object are acquired from multiple views using either single camera or multiple cameras. The images are then processed to produce silhouettes. The silhouettes are used to reconstruct a 3D object. The volume and surface area of the object are measured from the reconstructed object by mathematical modeling or by counting the number of voxels. 
3.3.2.1. Wire frame model. Lee et al. used a single camera and a turntable to acquire multiple silhouettes of the object [25]. The object is placed on a turntable and the rotation of the turntable is controlled such that images could be taken in fixed angular intervals using a fixed camera. The images are processed to make silhouettes and then extracted to obtain 2D object contours. 2D object contours are then transformed to 3D to obtain 3D object contours. A wire frame model is assembled from 3D object contours based on their centerline and their angular position. Linear interpolation is implemented by drawing a straight line between the corresponding boundary points from two adjacent contours. Object cross sections that are perpendicular to $\mathrm{z}$ axis from two consecutive contours form two pie shaped slices, one of each side of the $\mathrm{z}$ axis as shown in figure 6 . The area of each slice is approximated by the triangle area. The required dimensional attributes are the sides of triangle $\left(r_{i}\right)$, the angular interval of imaging $\operatorname{system}(\Delta \theta)$, the total number of slices $(N=2 \times 180 / \Delta \theta)$, and the thickness of slices. $(\Delta z=1)$

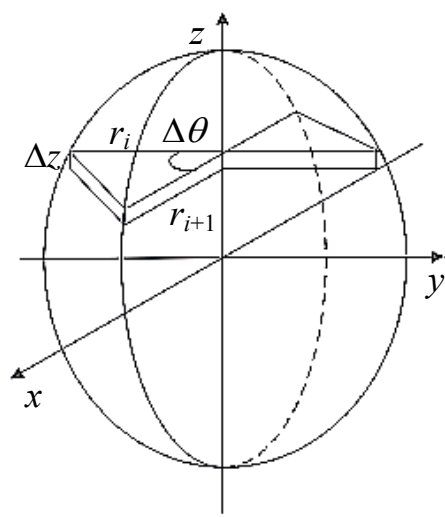

Figure 6. The required dimensional attributes for wire frame model

The area $A(z)$ of the whole cross section from a specific $z$ is approximated by the sum of the areas of all slices, as in equation (19).

$$
A(z)=\sum_{i=1}^{N} \frac{1}{2} r_{i} r_{(i+1) \bmod N} \sin \Delta \theta
$$

and the object volume $(V)$ is approximated by equation (20).

$$
V=\sum_{j=1}^{M} \sum_{i=1}^{N} \frac{1}{2} r_{i} r_{(i+1) \bmod N} \sin \Delta \theta \Delta z=\sum_{j=1}^{M} \sum_{i=1}^{N} \frac{1}{2} r_{i} r_{(i+1) \bmod N} \sin \Delta \theta
$$

Similarly, the perimeter $P(z)$ of the whole cross section at a specific $z$ is approximated by the cosine rule for triangle, as in equation (21).

$$
P(z)=\sum_{i=1}^{N} \sqrt{r_{i}^{2} r_{(i+1) \bmod N}^{2}-2 r_{i} r_{(i+1) \bmod N} \cos \Delta \theta}
$$

and the surface area $(S)$ is calculated by equation (22).

$$
S=\sum_{j=1}^{M} \sum_{i=1}^{N} \sqrt{r_{i}^{2} r_{(i+1) \bmod N}^{2}-2 r_{i} r_{(i+1) \bmod N} \cos \Delta \theta} \Delta z=\sum_{j=1}^{M} \sum_{i=1}^{N} \sqrt{r_{i}^{2} r_{(i+1) \bmod N}^{2}-2 r_{i} r_{(i+1) \bmod N} \cos \Delta \theta}
$$

3.3.2.2. Space carving method. In the space carving method Chalidabhongse, Yimyam, and Sirisomboon used four cameras for image acquisition [24]. A camera is on the top of the object and three cameras are around the object. Initially a large bounding box is constructed to be an initial volume enclosing the $3 \mathrm{D}$. Voxel space containing $n^{3}$ voxels is generated by dividing the whole initial volume into a cubical volume. Each voxel is projected onto the images by using intrinsic camera 
parameters, which are focal length $\left(f_{x}, f_{y}\right)$ principal point coordinates $\left(O_{x}, O_{y}\right)$, skew coefficient (S) and image radial and tangential distortion coefficients $(k c)$; and extrinsic camera parameters which are the rotation matrix $(\mathbf{R})$ and translation vector $(\mathbf{T})$.

If the projection of the voxel is inside the silhouette for all images then it is considered as an object voxel, otherwise it is removed from the volume. The volume of object is measured by counting the number of object voxels of the reconstructed object and the surface area of the object is measured by counting the number of object voxels that are located on surface of the reconstructed object.

3.3.2.3. Lofting method. Goñi et al. used destructive methods for acquiring images [26]. The object is sliced along selected axes and captured using a camera slice by slice. A subset of boundary pixels of each sliced object is interpolated by a closed B-spline curve to make a continuous approximation of the boundary. B-spline curves are then correctly assembled by using a lofting technique. A closed Non-Uniform Rational B-Spline (NURBS) surface is constructed through B-spline cross section curves. The surface is then converted to a 3D solid object.

A Finite Element Method (FEM) approach is developed to estimate volume and surface area of the reconstructed object. A mesh is generated using curved mesh elements and the Delaunay algorithm. Gaussian integration 4 th order is used over all boundaries $\left(\Gamma_{i}\right)$ and domains $\left(\Omega_{i}\right)$ to obtain estimated volume (V) and surface area (S) values using equation (23) and (24).

$$
\begin{gathered}
V=\sum_{i} \iiint_{\Omega_{i}} d \Omega_{i} \\
S=\sum_{i} \iint_{\Gamma_{i}} d \Gamma_{i}
\end{gathered}
$$

3.3.2.4. Volume intersection method. Castillo-Castaneda and Turchiuli [33] used a single camera and a turntable to acquire multiple silhouettes of an object as in [25]. A two-dimensional coordinate $S_{i}=\left(y s_{i j}, z s_{i j}\right)$ is defined as the coordinate of the silhouette in image i. The coordinate $S_{i}$ was then used to define three-dimensional projection coordinate $P_{i}=\left(x p_{i j}, y p_{i j}, z p_{i j}\right)$ at angle $\theta_{i}$. The coordinate $P_{i}$ was used to generate partial volume coordinate $V_{i}=\left(x v_{i j k}, y v_{i j k}, z v_{i j k}\right)$ by $\mathrm{M}$ translations that are normal to the plane of the projection $P_{i}$. The total volume of the object is given by the intersection of $\mathrm{N}$ partial volume $V_{i}$, as shown in equation (25).

$$
V_{T}=\bigcap_{i=1}^{N} V_{i}
$$

The volume of the object is approximated by counting the number of voxels belonging to the intersections.

\section{Application of Color Measurement in Food Products Inspection}

Although RGB color space is non-linear with regard to the visual perception of human eyes, color measurement of some food products is performed in this space. Color features in food product inspection are also measured in HSI, HSL, HSV, La*b*, and a color index. However XYZ color space is sometimes used in the transformation from RGB color space to La*b* color space [34][14]. RGB color space has been applied for quality inspection of bean base on color [1], palm oil fresh fruit bunch color grading [35], and tomato paste color prediction in $\mathrm{L}, \mathrm{a}^{*}, \mathrm{~b}^{*}$, and $\mathrm{a}^{*} / \mathrm{b}^{*}$ [23]. HSI color space has been used in apple color grading [12] and color visual inspection of muffins [22]. HSL color space has 
been used in real-time inspection of biscuits on a moving conveyor belt [36]. La*b* color space has been applied in investigation of the drying effect on color change of apple discs [2]. The color index has been used in date and tomato maturity evaluation [16]. Furthermore, the combination of RGB and HSI, HSI and La*b*, HSV and La*b* have also been used for the inspection of food products as listed in table 1.

Table 1 summarizes applications of color measurement in food product inspection and corresponding features, learning techniques, and accuracy. As shown in table 1, color features, such as the value, mean, variance, or standard deviation of each channel in corresponding color space or color index are widely used. Moreover the $\mathrm{H}$ value histogram, moment, and color texture are also used in some applications. Accuracy is measured using either classification rate or correlation coefficient. Various types of classifiers, such as neural networks, regression models, support vector machines, genetic algorithms, principal component analysis, and discriminant analysis are used for object classification and determination of correlation coefficients. However, a simple manual threshold is used as the learning technique in date and tomato maturity evaluation using a color index and yield high accuracy [16].

The most levels of accuracy is greater than 0.700; the higher accuracy is achieved in prediction of $\mathrm{a}^{*} / \mathrm{b}^{*}$ ratio in tomato paste using ANN (0.987) [23]. This result is consistent with the result obtained by [11] in estimating the value of $\mathrm{La}^{*} \mathrm{~b}^{*}$ from RGB. Furthermore, León et, al. have reported that the best results in estimating the value of $\mathrm{La}^{*} \mathrm{~b} *$ from RGB were obtained using neural network and full quadratic models with error close to $1 \%$ [11]. For product classification, the higher accuracy is achieved in color score of beef fat determinations using RGB and HIS color space and SVM (0.974) [15]; and in date maturity evaluation using color index and manual threshold (0.974) [16]. Results in table 1 show that color measurement of food products in RGB space can still provide a good result although this space is non-linear with regard to the visual perception of human eyes theoretically. Furthermore, with a small variation in color of a food product, the color index is an easier alternative to measure the color of the food product.

Table 1. The application of color measurement in food products inspection

\begin{tabular}{|c|c|c|c|c|c|c|}
\hline Products & Applications & $\begin{array}{l}\text { Color } \\
\text { space }\end{array}$ & Features & $\begin{array}{l}\text { Learning } \\
\text { techniques }\end{array}$ & Accuracy & Refs. \\
\hline Apple & Apple color grading & HIS & $\mathrm{H}$ value histogram & PSO NN ${ }^{\mathrm{a}}$ & 0.940 & $\begin{array}{l}\text { Haiyan\&Jinli } \\
\text { (2006) }\end{array}$ \\
\hline Apple & Apple color grading & $\begin{array}{l}\text { RGB, } \\
\text { HIS }\end{array}$ & $\begin{array}{l}\text { mean and variance } \\
\text { of } R, G, B ; r^{w}, g^{x}, b^{y} \\
\text { value, } H \text { value } \\
\text { histogram }\end{array}$ & $\mathrm{OFP}^{\mathrm{b}}, \mathrm{GA}^{\mathrm{c}}$ & 0.847 & $\begin{array}{l}\text { Xiaobo et al. } \\
\text { (2007) }\end{array}$ \\
\hline Apple & $\begin{array}{l}\text { Effect of drying on color } \\
\text { change of apple disc }\end{array}$ & $\mathrm{La}^{*} \mathrm{~b} *$ & $\mathrm{~L}, \mathrm{a}^{*}, \mathrm{~b}^{*}$ value & - & $0.910-0.950$ & $\begin{array}{l}\text { Fernandez, at } \\
\text { al. }(2005)\end{array}$ \\
\hline Bean & $\begin{array}{l}\text { Quality inspection of beans } \\
\text { based on color } \\
\text { quantification }\end{array}$ & RGB & $\begin{array}{l}\text { mean, standart } \\
\text { deviation,skewness, } \\
\text { and kurtosis of R, } \\
\text { G, B value }\end{array}$ & $\mathrm{ANN}^{\mathrm{d}}$ & 0.906 & $\begin{array}{l}\text { Kilıç et al. } \\
(2007)\end{array}$ \\
\hline Beef & $\begin{array}{l}\text { Determine color scores of } \\
\text { beef fat }\end{array}$ & $\begin{array}{l}\text { RGB, } \\
\text { HIS }\end{array}$ & $\begin{array}{l}\text { mean and standart } \\
\text { deviation of } R, G, \\
B, H, S, I \text { value }\end{array}$ & $\mathrm{SVM}^{\mathrm{e}}$ & 0.974 & $\begin{array}{l}\text { Chen, et al. } \\
\text { (2010) }\end{array}$ \\
\hline \multirow{2}{*}{ Beef } & \multirow{2}{*}{$\begin{array}{l}\text { Moisture content estimation } \\
\text { of large cooked beef joints }\end{array}$} & \multirow{2}{*}{$\begin{array}{l}\text { RGB, } \\
\text { HIS }\end{array}$} & \multirow{2}{*}{$\begin{array}{l}\text { mean and standart } \\
\text { deviation of } R, G, \\
B, H, S, I \text { value }\end{array}$} & $\operatorname{PLSR}^{\mathrm{f}}$ & 0.560 & \multirow{2}{*}{$\begin{array}{l}\text { Zheng, et al. } \\
\text { (2006) }\end{array}$} \\
\hline & & & & $\mathrm{NN}^{\mathrm{g}}$ & 0.750 & \\
\hline Biscuit & $\begin{array}{l}\text { Real-time inspection of } \\
\text { biscuits on moving } \\
\text { conveyor belt }\end{array}$ & HSL & $\mathrm{H}$ value & $\begin{array}{l}\text { Wilk's } \lambda \\
\text { analysis, } \\
\text { SVM }\end{array}$ & 0.960 & $\begin{array}{l}\text { Nashat et al. } \\
(2011)\end{array}$ \\
\hline
\end{tabular}




\begin{tabular}{|c|c|c|c|c|c|c|}
\hline Products & Applications & $\begin{array}{l}\text { Color } \\
\text { space }\end{array}$ & Features & $\begin{array}{l}\text { Learning } \\
\text { techniques }\end{array}$ & Accuracy & Refs. \\
\hline \multirow{2}{*}{ Broccoli } & \multirow{2}{*}{ Broccoli grading } & \multirow{2}{*}{$\begin{array}{l}\mathrm{HSI} \\
\mathrm{La}^{*} \mathrm{~b} *\end{array}$} & \multirow{2}{*}{$\mathrm{b}^{*}$ value, $\mathrm{TCD}^{\mathrm{u}}, \mathrm{H}^{0 \mathrm{v}}$} & & 0.569 & \multirow{2}{*}{$\begin{array}{l}\text { Kang et al. } \\
(2007)^{z}\end{array}$} \\
\hline & & & & $\mathrm{BP} \mathrm{NN}{ }^{\mathrm{i}}$ & 0.934 & \\
\hline Date & Date maturity evaluation & $\begin{array}{l}\text { Color } \\
\text { index }\end{array}$ & mean of color index & $\begin{array}{l}\text { Manual } \\
\text { threshold }\end{array}$ & $0.868-0.974$ & $\begin{array}{l}\text { Dah-Jye et } \\
\text { al. }(2011)\end{array}$ \\
\hline Muffin & $\begin{array}{l}\text { Color visual inspection of } \\
\text { muffin }\end{array}$ & HIS & $\mathrm{H}$ value histogram & $\mathrm{DA}^{\mathrm{j}}$ & 0.880 & $\begin{array}{l}\text { Abdullah et } \\
\text { al. }(2000)\end{array}$ \\
\hline $\begin{array}{l}\text { Palm oil } \\
\text { fresh } \\
\text { fruit } \\
\text { bunches }\end{array}$ & $\begin{array}{l}\text { Palm oil fresh fruit bunches } \\
\text { color grading }\end{array}$ & RGB & $\begin{array}{l}\text { mean and variance } \\
\text { of } R, G, B \text { value }\end{array}$ & $\mathrm{NF}^{\mathrm{k}}$ & 0.733 & $\begin{array}{l}\text { Jamil et al. } \\
\text { (2009) }\end{array}$ \\
\hline $\begin{array}{l}\text { Potato } \\
\text { chips }\end{array}$ & $\begin{array}{l}\text { Classification of } \\
\text { commercial potato chips }\end{array}$ & $\begin{array}{l}\text { XYZ, } \\
\text { HSV, } \\
\mathrm{La}^{*}{ }^{*}\end{array}$ & $\begin{array}{l}\text { mean, energy, } \\
\text { entropy, contras, } \\
\text { homogeneity of L, } \\
\mathrm{a}^{*}, \mathrm{~b}^{*}, \mathrm{H}, \mathrm{S}, \mathrm{V} \text {, } \\
\text { Grey level intensity } \\
\text { value }\end{array}$ & $\begin{array}{l}\mathrm{PCA}^{1} \\
\mathrm{LDA}^{\mathrm{m}}\end{array}$ & 0.900 & $\begin{array}{l}\text { Mendoza, et } \\
\text { al. (2007) }\end{array}$ \\
\hline Rice & $\begin{array}{l}\text { Classification of milled rice } \\
\text { kernel base on color }\end{array}$ & $\begin{array}{l}\text { RGB, } \\
\mathrm{La}^{*} \mathrm{~b} *\end{array}$ & $\begin{array}{l}\text { Range, mean, } \\
\text { standard deviation, } \\
\text { median of R, G, B, } \\
\mathrm{L}, \mathrm{a}^{*}, \mathrm{~b}^{*} \text { value }\end{array}$ & $\mathrm{PNN}^{\mathrm{n}}$ & 0.94 & $\begin{array}{l}\text { Agustin \& } \\
\text { Byung-Joo } \\
\text { (2008) }\end{array}$ \\
\hline \multirow{2}{*}{ Shrimp } & \multirow{2}{*}{$\begin{array}{l}\text { Moisture content estimation } \\
\text { in dehydrated shrimp }\end{array}$} & \multirow{2}{*}{$\begin{array}{l}\mathrm{XYZ} \\
\mathrm{La}{ }^{*}{ }^{*}\end{array}$} & \multirow{2}{*}{$\begin{array}{l}\text { mean and variance } \\
\text { of } L, a^{*}, b^{*} \text { value }\end{array}$} & MLR & 0.800 & \multirow{2}{*}{$\begin{array}{l}\text { Mohebbi, et } \\
\text { al. (2009) }\end{array}$} \\
\hline & & & & $\mathrm{ANN}^{\mathrm{d}}$ & 0.860 & \\
\hline Tomato & Tomato maturity evaluation & $\begin{array}{l}\text { Color } \\
\text { index }\end{array}$ & mean of color index & $\begin{array}{l}\text { Manual } \\
\text { threshold }\end{array}$ & 0.950 & $\begin{array}{l}\text { Dah-Jye et } \\
\text { al. (2011) }\end{array}$ \\
\hline \multirow{4}{*}{$\begin{array}{l}\text { Tomato } \\
\text { paste }\end{array}$} & \multirow{4}{*}{$\begin{array}{l}\text { Tomato paste color in } \mathrm{L}, \mathrm{a}^{*} \text {, } \\
\mathrm{b}^{*} \text {, and } \mathrm{a}^{*} / \mathrm{b}^{*} \text { prediction }\end{array}$} & \multirow{4}{*}{ RGB } & \multirow{4}{*}{$\mathrm{R}, \mathrm{G}, \mathrm{B}$ value } & $\mathrm{LM}^{\mathrm{o}}$ & $0.036-0.693$ & \multirow{4}{*}{$\begin{array}{l}\text { Velioğlu, et } \\
\text { al. (2011) }\end{array}$} \\
\hline & & & & $\mathrm{QM}^{\mathrm{p}}$ & $0.032-0.729$ & \\
\hline & & & & $\mathrm{FQM}^{\mathrm{q}}$ & $0.224-0.662$ & \\
\hline & & & & $\mathrm{ANN}^{\mathrm{d}}$ & $0.889-0.987$ & \\
\hline
\end{tabular}

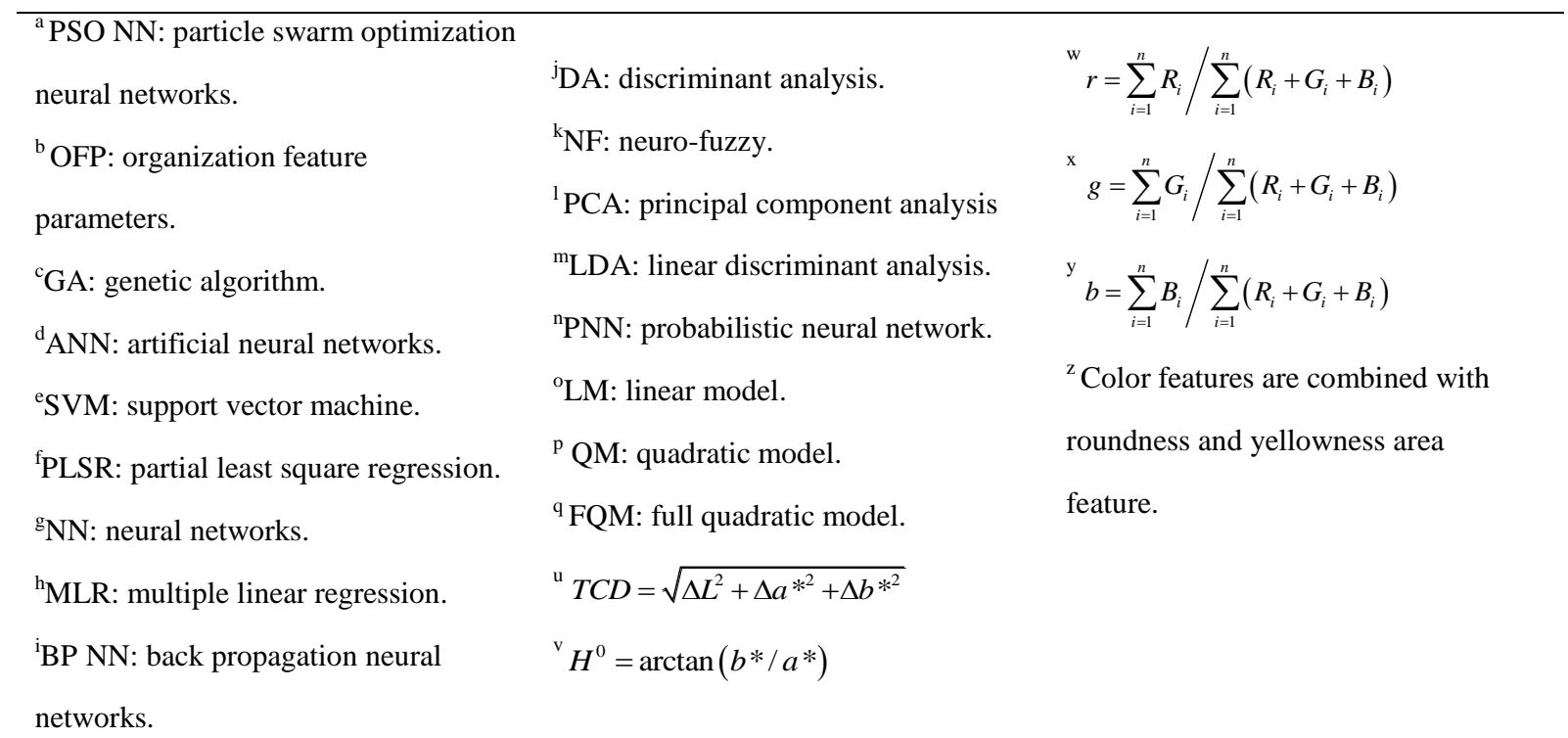




\section{Application of Size Measurement in Food Products Inspection}

Besides estimating the size of the food product, size measurement can be also used for sorting or grading such as sorting mango [24], detecting unwanted objects such as predicting total coli form bacteria in foods [37], detecting defects such as determination of dark specks in tomato paste, and estimating other physical properties such as estimating weight of milled rice kernel [38] as mentioned in table 2. Previous studies in size measurement and its application in food product inspection are summarized in table 2 together with corresponding methods, features, learning techniques and accuracy.

As shown in table 2, size measurement of food product involves length, width, thickness, average radius, Feret's Diameter, area, perimeter, volume and surface area. For object classification or determination of correlation coefficient, statistical classifier, artificial, and back propagation neural networks, and linear regression are used as learning techniques. In measuring accuracy, the result of size measurement using computer vision is compared to the result of size measurement using laboratory equipment such as calipers for length and width, or using water displacement based on Archimedes's principle for volume. Furthermore, for area and surface area measurement, accuracy is obtained by comparing to mathematical models from previous studies or by comparing with other measured physical property such as weight. Besides classification rate and correlation coefficient, average percentage error and average percentage absolute error are used to measure accuracy. For volume and surface area measurement, many researchers assume that the food product is axisymmetric. This follows from the fact that most food products such as egg, orange, lemon, apple, and watermelon have an axi-symmetric or almost axi-symmetric shape. Moreover, with this assumption the calculation of volume and surface area is much simpler and provides a good accuracy.

Table 2. The application of size measurement in food products inspection

\begin{tabular}{|c|c|c|c|c|c|c|}
\hline Products & Applications & Method & Features & $\begin{array}{l}\text { Learning } \\
\text { techniques }\end{array}$ & Accuracy & Refs. \\
\hline $\begin{array}{l}\text { Apple, } \\
\text { Meat }\end{array}$ & $\begin{array}{l}\text { Estimating volume and } \\
\text { surface area }\end{array}$ & Lofting & $\begin{array}{l}\text { Volume, surface } \\
\text { area }\end{array}$ & - & $\begin{array}{l}0.992- \\
0.998^{\mathrm{a}}(\mathrm{V}) \\
0.934- \\
0.983^{\mathrm{a}}(\mathrm{SA})\end{array}$ & $\begin{array}{l}\text { Goñi, et al. (2007) } \\
\text { (Goñi et al. 2007) }\end{array}$ \\
\hline Apple & Classification of apple disc & - & $\begin{array}{l}\text { Average radius, } \\
\text { area, perimeter, } \\
\text { Feret's diameter }\end{array}$ & $\mathrm{SCL}^{\mathrm{k}}$ & $0.950^{\mathrm{d}}$ & $\begin{array}{l}\text { Fernandez, at al. } \\
\text { (2005) }\end{array}$ \\
\hline \multirow{3}{*}{$\begin{array}{l}\text { Apple, } \\
\text { cantaloupe, } \\
\text { strawberry, } \\
\text { tomato }\end{array}$} & \multirow{3}{*}{$\begin{array}{l}\text { Fruits volume and surface } \\
\text { area measurement }\end{array}$} & \multirow{3}{*}{$\mathrm{WF}^{\mathrm{e}}$} & \multirow{3}{*}{$\begin{array}{l}\text { Volume, surface } \\
\text { area }\end{array}$} & \multirow{3}{*}{ - } & $0.025^{\mathrm{b}}\left(\mathrm{V}^{\mathrm{o}}\right)$ & \multirow{3}{*}{ Lee et al. (2006) } \\
\hline & & & & & $\begin{array}{l}0.024^{\mathrm{b}}\left(\mathrm{SA}^{\mathrm{p}}\right) \\
0.956^{\mathrm{a}}\left(\mathrm{V}^{\mathrm{o}}\right)\end{array}$ & \\
\hline & & & & & $0.926^{\mathrm{a}}\left(\mathrm{SA}^{\mathrm{p}}\right)$ & \\
\hline Bean & $\begin{array}{l}\text { Estimating length and } \\
\text { width of bean }\end{array}$ & - & Length, width & - & $\begin{array}{l}0.984^{\mathrm{a}}\left(1^{\mathrm{q}}\right) \\
0.971^{\mathrm{a}}\left(\mathrm{w}^{\mathrm{r}}\right)\end{array}$ & Kiliç et al. (2007) \\
\hline $\begin{array}{l}\text { Biscuit, } \\
\text { bread, cake }\end{array}$ & $\begin{array}{l}\text { Predicting total coli form } \\
\text { bacteria in foods }\end{array}$ & - & $\begin{array}{l}\text { Length, width, } \\
\text { area, perimeter }\end{array}$ & $\mathrm{ANN}^{1}$ & $0.972^{\mathrm{a}}$ & $\begin{array}{l}\text { Yin \& Ding } \\
(2009)^{2}\end{array}$ \\
\hline Egg & Volume measurement & $\mathrm{PT}^{\mathrm{u}}$ & Volume & - & $0.990-0.993^{\mathrm{a}}$ & $\begin{array}{l}\text { Soltani et al. } \\
\text { (2014) }\end{array}$ \\
\hline $\begin{array}{l}\text { Egg, } \\
\text { Lemon, } \\
\text { Lime, } \\
\text { Tamarillo }\end{array}$ & $\begin{array}{l}\text { volume and surface area } \\
\text { measurement }\end{array}$ & $\mathrm{CF}^{\mathrm{f}}$ & $\begin{array}{l}\text { Volume, surface } \\
\text { area }\end{array}$ & - & $\begin{array}{l}0.032-0.067^{\mathrm{b}} \\
\left(\mathrm{V}^{\mathrm{o}}\right) \\
0.028-0.042^{\mathrm{b}} \\
\left(\mathrm{SA}^{\mathrm{p}}\right)\end{array}$ & $\begin{array}{l}\text { Wang \& Nguang } \\
\text { (2007) }\end{array}$ \\
\hline
\end{tabular}




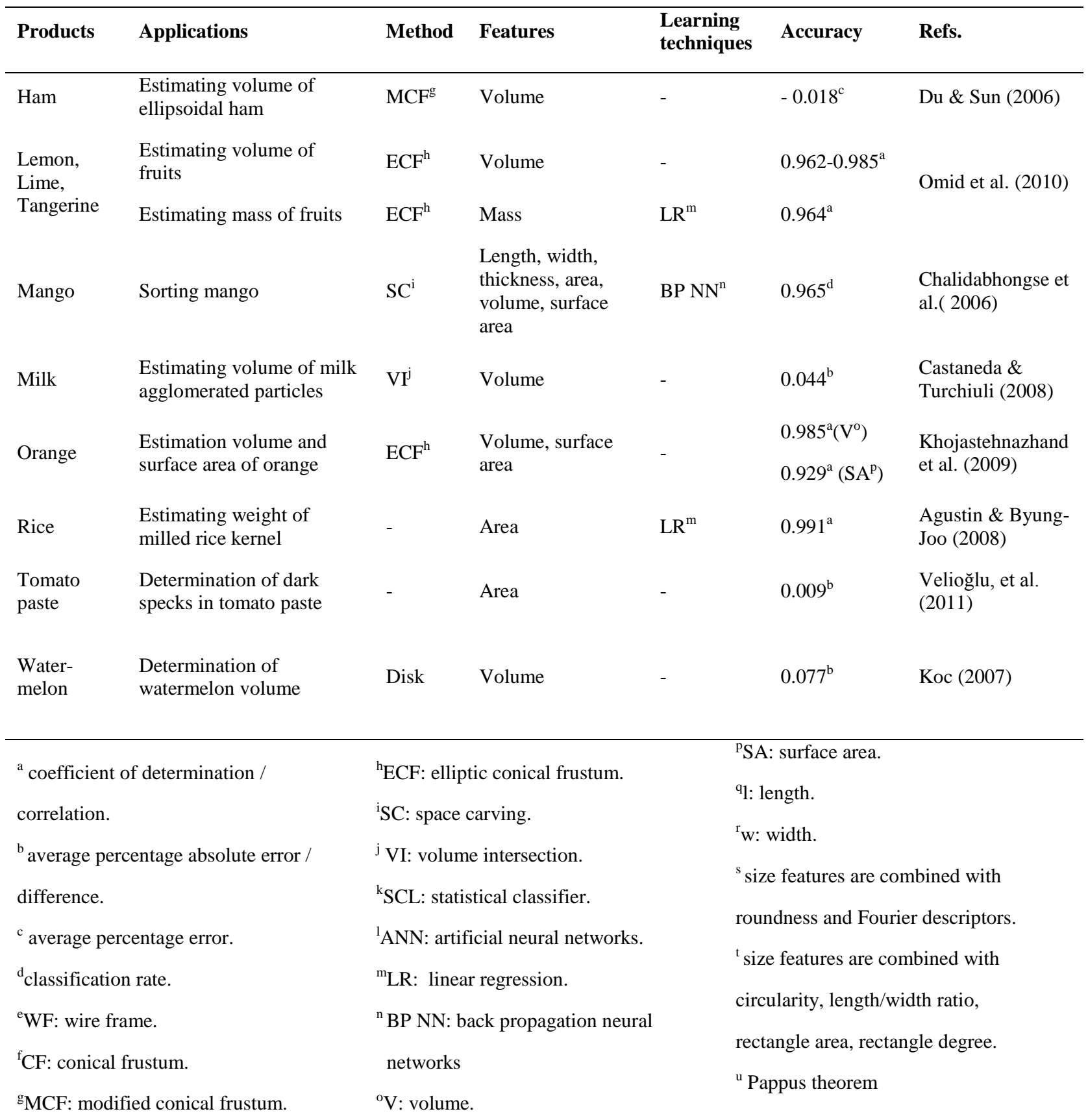

Generally, the accuracy of size measurement is difficult to compare due to the difference in accuracy measurement. For axi-symmetric objects, the higher accuracy of volume and surface area measurement are achieved in estimating orange volume using elliptic conical frustum (0.985) [31][39] estimating egg volume using conical frustum (0.032) [29], in estimating orange surface area using elliptic conical frustum (0.929) [31], and estimating tamarillo surface area using conical frustum (0.028) [29]. The accuracy of the disk method and the conical frustum method depends on the number of partitions (i.e. the number of disks or conical frustums) used in the calculation. The higher the number of partitions the higher the accuracy is, but this condition can decrease the speed of calculation. For the calculation of citrus fruits, Omid, Khojastehnazhand, and Tabatabaeefar used the number of partition $n=8$ to speed-up the calculation [39]. However, they suggested that for other axisymmetric agricultural products with irregular surfaces such as peppers or carrots higher values of $\mathrm{n}$ is recommended. For irregular shaped objects, the higher accuracy is achieved in estimating volume and 
surface area of Red delicious apple using the lofting method (0.998 and 0.983 resp.) [26]. Although the lofting method gives a better accuracy there is a drawback in this method. Each object should be sliced prior to measurement; therefore this method is considered as destructive.

\section{Conclusions}

In purchasing a food product, a consumer will firstly consider the external aspect of the product such as color and size. Recently color and size have been used for inspecting a food product using computer vision. Five color spaces are widely used to measure color features of a food product, namely RGB, HSI, HSL, HSV, and La*b*. However XYZ color space is sometimes used in the transformation from RGB color space to La*b* color space. A one dimensional color index is an alternative method for the color measurement of food products. Moreover, the color index can easily be used to classify a food product based on color features. Color features, such as the value, mean, variance, or standard deviation of each channel in the corresponding color space or color index are widely used. From previous studies it is shown that color measurement can be applied for grading, detecting the presence of a particular anomaly or damage in the product, detection of the specific content in food products and evaluation of changes in product color during processing.

Size measurement of a food product includes one dimensional size measurements of length, width, thickness, average radius, and Feret's diameter; two dimensional size measurements of area and perimeter; and three dimensional size measurements of volume and surface area. One and two dimensional size measurements can be directly obtained from the image of the measured object. However measuring volume and surface area requires a further method namely disk, conical frustum, and elliptic conical frustum methods for axi-symmetric objects and wire frame model, space carving, lofting, and the volume intersection method for irregular shaped objects. Some applications of size measurement in food product inspection are for estimating size, sorting or grading, detection of unwanted objects or defects, and measurement of other physical properties of food products. Although volume and surface area measurement are more difficult, they have a very important role in the production and processing of food products. Therefore research in volume and surface area measurement of food products is a very challenging task.

\section{References}

[1] K. Kiliç, I. H. Boyaci, H. Köksel, and I. Küsmenoglu, "A classification system for beans using computer vision system and artificial neural networks," J. Food Eng., vol. 78, no. 3, pp. 897904, 2007.

[2] L. Fernández, C. Castillero, and J. M. Aguilera, "An application of image analysis to dehydration of apple discs," J. Food Eng., vol. 67, no. 1-2, pp. 185-193, 2005.

[3] M. Z. Abdullah, Image Acquisition Systems. Amsterdam: Academic Press, 2008.

[4] K. K. Patel, A. Kar, S. N. Jha, and M. A. Khan, "Machine vision system: A tool for quality inspection of food and agricultural products," Journal of Food Science and Technology, vol. 49, no. 2. pp. 123-141, 2012.

[5] N. Kondo, "Automation on fruit and vegetable grading system and food traceability," Trends Food Sci. Technol., vol. 21, no. 3, pp. 145-152, 2010.

[6] A. S. Prabuwono, R. Sulaiman, A. R. Hamdan, and A. Hasniaty, "Development of Intelligent Visual Inspection System (IVIS) for bottling machine," in IEEE Region 10 Annual International Conference, Proceedings/TENCON, 2007, pp. 1-4.

[7] C. Zheng, D. W. Sun, and L. Zheng, "Correlating colour to moisture content of large cooked beef joints by computer vision," J. Food Eng., vol. 77, no. 4, pp. 858-863, 2006.

[8] E. N. Malamas, E. G. M. Petrakis, M. Zervakis, L. Petit, and J. D. Legat, "A survey on industrial vision systems, applications and tools," Image and Vision Computing, vol. 21, no. 2. pp. 171-188, 2003.

[9] D. T. Pham and R. J. Alcock, Smart Inspection Systems: Techniques and Applications of Intelligent Vision. 2003.

[10] H. Akbar and A. S. Prabuwono, "The design and development of automated visual inspection system for press part sorting," in Proceedings of the International Conference on Computer 
Science and Information Technology, ICCSIT 2008, 2008, pp. 683-686.

[11] K. León, D. Mery, F. Pedreschi, and J. León, "Color measurement in L*a*b*units from RGB digital images," Food Res. Int., pp. 1084-1091, 2006.

[12] J. Haiyan and Y. Jinli, "The application study of apple color grading by particle swarm optimization neural networks," in Proceedings of the World Congress on Intelligent Control and Automation (WCICA), 2006, pp. 2651-2654.

[13] Z. Xiaobo, Z. Jiewen, and L. Yanxiao, "Apple color grading based on organization feature parameters," Pattern Recognit. Lett., pp. 2046-2053, 2007.

[14] M. Mohebbi, M. R. Akbarzadeh-T, F. Shahidi, M. Moussavi, and H. B. Ghoddusi, "Computer vision systems (CVS) for moisture content estimation in dehydrated shrimp," Comput. Electron. Agric., pp. 128-134, 2009.

[15] K. Chen, X. Sun, C. Qin, and X. Tang, "Color grading of beef fat by using computer vision and support vector machine," Comput. Electron. Agric., pp. 27-32, 2010.

[16] D. J. Lee, J. K. Archibald, and G. Xiong, "Rapid color grading for fruit quality evaluation using direct color mapping," IEEE Trans. Autom. Sci. Eng., pp. 292-302, 2011.

[17] C. Zheng and D. W. Sun, "Object Measurement Methods," in Computer Vision Technology for Food Quality Evaluation, 2008.

[18] A. Ford and A. Roberts, "Colour Space Conversions," Retrieved January, 1998.

[19] M. Tkalčič and J. F. Tasič, "Colour spaces - Perceptual, historical and applicational background," in IEEE Region 8 EUROCON 2003: Computer as a Tool - Proceedings, 2003, pp. 304-308.

[20] R. C. Gonzalez and R. E. Woods, Digital Image Processing, 2nd ed. New Jersey: Prentice Hall, 2002.

[21] W. Chen, Y. Q. Shi, and G. Xuan, "Identifying Computer Graphics using HSV Color Model and Statistical Moments of Characteristic Functions," in Multimedia and Expo, 2007 IEEE International Conference on, 2007, pp. 1123-1126.

[22] M. Z. Abdullah, S. A. Aziz, and A. M. Dos Mohamed, "Quality inspection of bakery products using a color-based machine vision system," J. Food Qual., pp. 39-50, 2000.

[23] H. M. Velioĝlu, smail H. Boyaci, and Ş. Kurultay, "Determination of visual quality of tomato paste using computerized inspection system and artificial neural networks," Comput. Electron. Agric., pp. 147-154, 2011.

[24] T. Chalidabhongse, P. Yimyam, and P. Sirisomboon, "2D/3D vision-based mango's feature extraction and sorting," in 9th International Conference on Control, Automation, Robotics and Vision, 2006, ICARCV '06, 2006, pp. 1-6.

[25] D.-J. Lee, X. Xu, J. D. Eifert, and P. Zhan, "Area and volume measurements of objects with irregular shapes using multiple silhouettes," Opt. Eng., vol. 45, no. 2, p. 027202, 2006.

[26] S. M. Goñi, E. Purlis, and V. O. Salvadori, "Three-dimensional reconstruction of irregular foodstuffs," J. Food Eng., pp. 536-547, 2007.

[27] A. B. Koc, "Determination of watermelon volume using ellipsoid approximation and image processing," Postharvest Biol. Technol., pp. 366-371, 2007.

[28] E. S. Bridge, R. K. Boughton, R. A. Aldredge, T. J. E. Harrison, R. Bowman, and S. J. Schoech, "Measuring egg size using digital photography: Testing Hoyt's method using Florida Scrub-Jay eggs," J. F. Ornithol., pp. 109-116, 2007.

[29] T. Y. Wang and S. K. Nguang, "Low cost sensor for volume and surface area computation of axi-symmetric agricultural products," J. Food Eng., pp. 870-877, 2007.

[30] C. J. Du and D. W. Sun, "Estimating the surface area and volume of ellipsoidal ham using computer vision," J. Food Eng., 2006.

[31] M. Khojastehnazhand, M. Omid, and A. Tabatabaeefar, "Determination of orange volume and surface area using image processing technique," Int. Agrophysics, pp. 237-242, 2009.

[32] M. Soltani, M. Omid, and R. Alimardani, "Egg volume prediction using machine vision technique based on pappus theorem and artificial neural network," J. Food Sci. Technol., 2014.

[33] E. Castillo-Castaneda and C. Turchiuli, "Volume estimation of small particles using three- 
dimensional reconstruction from multiple views," in Lecture Notes in Computer Science (including subseries Lecture Notes in Artificial Intelligence and Lecture Notes in Bioinformatics), 2008.

[34] F. Mendoza, P. Dejmek, and J. M. Aguilera, "Colour and image texture analysis in classification of commercial potato chips," Food Res. Int., pp. 1146-1154, 2007.

[35] N. Jamil, A. Mohamed, and S. Abdullah, "Automated grading of palm oil Fresh Fruit Bunches (FFB) using neuro-fuzzy technique," in SoCPaR 2009 - Soft Computing and Pattern Recognition, 2009, pp. 245-249.

[36] S. Nashat, A. Abdullah, S. Aramvith, and M. Z. Abdullah, "Support vector machine approach to real-time inspection of biscuits on moving conveyor belt," Comput. Electron. Agric., pp. 147-158, 2011.

[37] Y. guang Yin and Y. Ding, "A close to real-time prediction method of total coliform bacteria in foods based on image identification technology and artificial neural network," Food Res. Int., pp. 191-199, 2009.

[38] O. C. Agustin and B. J. Oh, "Automatic milled rice quality analysis," in Proceedings of the 2008 2nd International Conference on Future Generation Communication and Networking, FGCN 2008, 2008, pp. 112-115.

[39] M. Omid, M. Khojastehnazhand, and A. Tabatabaeefar, "Estimating volume and mass of citrus fruits by image processing technique," J. Food Eng., pp. 315-321, 2010. 